\title{
EVALUATION OF AN INNOVATIVE TEACHING METHODOLOGY FOR ENGINEERING INVOLVING COMPANIES AND ICTS IN A FLIPPED CLASSROOM
}

Evaluación de una metodología docente innovadora para ingeniería, involucrando empresas y TIC en una flipped classroom

Avaliação duma metodología de ensino innovadora para Engenharia, focada na participação das empresas e o uso dos TIC em uma flipped classroom

This work has been financially supported by the project INVIERTE-PRACTIC, belonging to the PAGID-2016 call, from the University of León (Spain).

\section{Fernando González-Andrés (1)}

Olegario Martínez-Morán (2)

Marta-Elena Sánchez-Morán (3)

\section{Xiomar-A. Gómez-Barrios (4)}

\section{Antonio Morán (5)}

\section{Beatriz Urbano-López-de-Meneses (6)}

(1) University of León, Spain. Teaching Innovation Group INGENIAQ. Telephone: +34 987291840. Email: fgona@unileon.es

(2) University of León, Spain. Teaching Innovation Group INGENIAQ. Email: omarm@unileon.es

(3) University of León, Spain. Teaching Innovation Group INGENIAQ. Email: mesanm@unileon.es

(4) University of León, Spain. Teaching Innovation Group INGENIAQ. Email: xagomb@unileon.es

(5) University of León, Spain. Teaching Innovation Group INGENIAQ. Email: amorp@unileon.es

(6) University of Valladolid, Spain. Teaching Innovation Group INGENIAQ. Telephone: +34 979108468. Correo electrónico: beaturb@iaf.uva.es 


\begin{abstract}
This work presents an innovative education experience for engineering students, with the objective of connecting students to labor market, in the context of the regular subject practices, with the analysis of real cases of companies, and using as tools the ICTs and the flipped learning methodology. The assessment of the impact of this innovation education action consisted on the creation of data bases, and the organization of lecturers' panels, and surveys for students and teachers. The most outstanding drawback raised by teachers was the lack of alignment between the companies' needs and the curricula of the students. The students appreciated this kind of activity in the subject practices. The students also considered positive the use of ICTs as part of this innovative teaching-learning process, which are familiar technologies for them. According to the teachers, the action contributed to improve autonomous and collaborative teaching in Higher Education.
\end{abstract}

Keywords: Engineering Higher Education; Labor Market; Practical education

\title{
Resumen
}

Este trabajo presenta una experiencia de innovación docente para los estudiantes de ingeniería, con objeto de acercarlos al mercado laboral, mediante las prácticas de las asignaturas, analizando casos reales de empresas con las que entrarán en contacto directo, utilizando como herramientas TIC y la metodología flipped learning. Para evaluar el impacto de la acción se crearon bases de datos con los casos reales resueltos, se desarrollaron paneles de docentes y se realizaron encuestas a los docentes y alumnos involucrados. El mayor inconveniente destacado por los docentes fue la falta de alineamiento entre las necesidades de las empresas y los curricula de los estudiantes. Los estudiantes valoraron positivamente la actividad y el uso de TIC como parte importante del proceso innovador de enseñanza-aprendizaje. De acuerdo con la opinión de los profesores, la acción contribuyó a mejorar el aprendizaje autónomo y colaborativo en la Enseñanza Superior.

Palabras clave: Educación Superior en Ingenierías; Mercado laboral; Educación práctica

Evaluation of an innovative teaching methodology for engineering involving companies and ICTs in a flipped classroom 


\section{Resumo}

Este trabalho apresenta uma experiência de inovação docente para os estudantes de engenharia com alvo de aproximá-los ao mercado laboral, por meio das práticas das disciplinas, analisando casos reais de empresas através das cuais entrarão em contato direto, usando como ferramentas as TICs e a metodologia “flipped learning”. Para avaliar o impacto da ação, foram criadas umas bases de dados com os casos reais resolvidos, se desenvolveram panéis de docentes e se realizaram inquéritos aos docentes e alunos implicados. A principal desvantagem para os docentes foi a falta de alinhameinto entre as necessidades das empresas e os currículos dos estudantes. Os estudantes valoraram positivamente a atividade e o uso das TICs como uma parte importante do processo inovador do ensino-aprendizagem. De acordo com a opinião dos professores, a ação ajudou a melhorar a aprendizagem autônoma e colaborativa no Ensino Superior.

Palavras-chave: Ensino Superior em Engenharia; Mercado laboral; Educação prática

\section{Introduction}

In 2014, the European Commission presented the Agenda for the Higher Education Modernization in order to align the modernization of the higher education with the objectives of the Europe Strategy 2020 (EACEA, 2014). The agenda established as a priority the adjustment of the higher education studies to the labor market promoting the entrepreneurial spirit and enhancing the links between education, research and enterprise.

Additionally, one of the most prominent characteristics of the present generation is their technology savviness and use of that technology in almost every aspect of their lives. Almost all the students in developed countries have a smart phone (Miller, 2014) spending on average 33 hours per week on the internet (Kilian et al., 2012), It is estimated that it won't be long before one-third of the world population will engage in some shape or form with social media (Web empresa, 2015). The University system must adapt to this momentum. 
The two aspects mentioned can be approached together by the use of flipped learning. It is reversal of traditional, teaching where students gain first exposure to the topic by the practices, and then class time is used to do the harder work of assimilating the knowledge through strategies such as discussion or debates that take the students to the concepts (Brame, 2013). "Flipping the classroom” has become a common word in education during the last years, driven in part by high profile publications in The New York Times (Fitzpatrick, 2012), the Chronicle of Higher Education (Berrett, 2012) and Science (Mazur, 2009).

The aim of the work was to assess an innovative and active teaching methodology for engineering studies, intended for regular subject practices, based on the involvement of companies and the use of ICTs, in a flipped classroom.

\section{Context}

Table 1 shows the level of High Education studies involved, as well as the subjects. The action was carried out during the academic course 2016-2017. The sample consisted on 68 students working in 54 real study cases (in some of them they worked in couples) from September 2016 to April 2017. Out of them $56.4 \%$ of the students were postgraduates and the rest undergraduate. The average age was 24 years old, half of them men (54.5\%), with an average of 2.4 years studying in the current level.

Table 1.

Subjects included in the education experience of connecting students and potential employers by flipped classroom and use of ICTs

\begin{tabular}{cll}
\hline \multicolumn{1}{c}{ Engineer Area } & \multicolumn{1}{c}{ Degree/Master } & \multicolumn{1}{c}{ Subject } \\
\hline Chemical Engineering & Degree in Biotechnology & Biotechnological Processes \\
& Master's Degree in Renewable Energy & Biofuels \\
& Degree in Energy Engineering & Bioenergy \\
\hline \multirow{2}{*}{ Agricultural Engineering } & Degree in Agricultural Engineering & Crops Production \\
& Master's Degree in Agricultural Engineering & Crops Production Systems \\
& & Agro-food Marketing \\
\hline
\end{tabular}

\section{Design and development}

The methodology was based on the flipped classroom, ICTs, and real study cases from companies according to the following stages (Figure 1). 


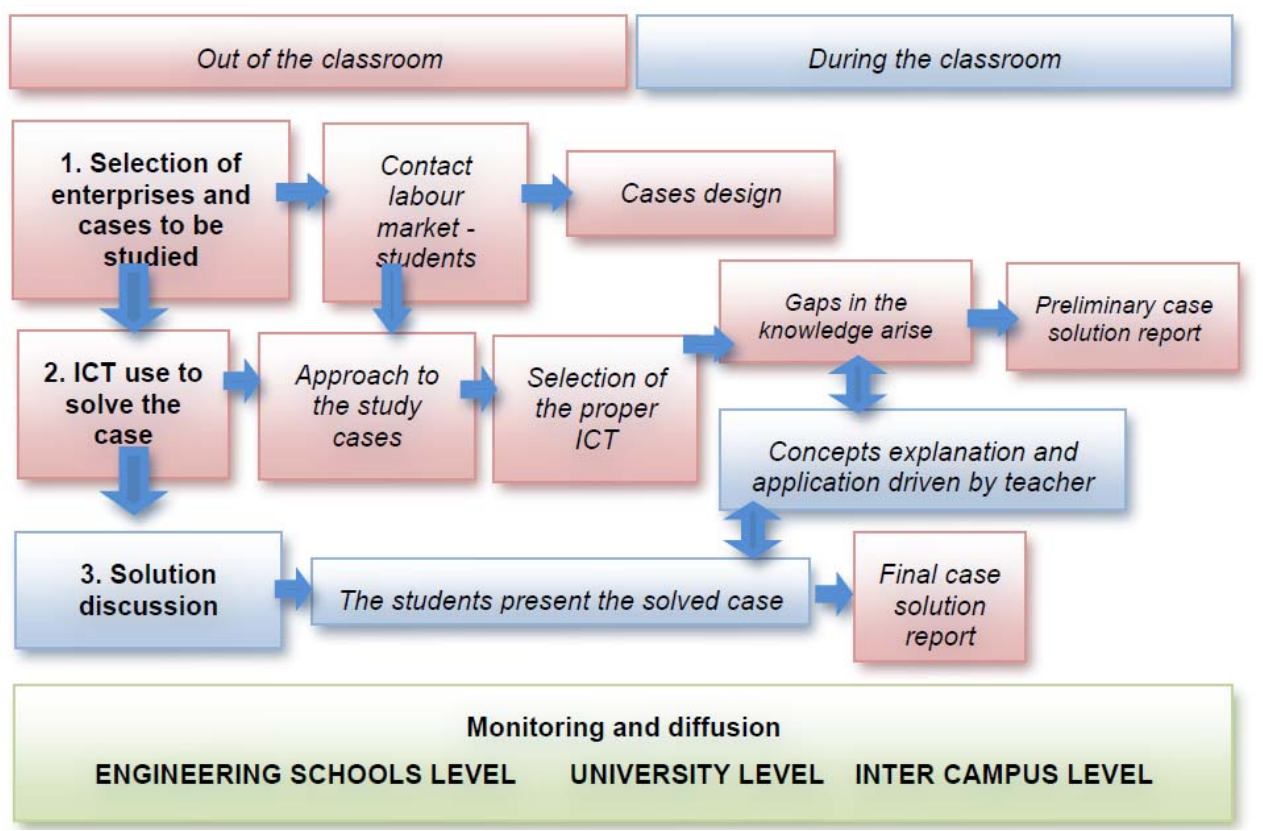

Figure 1.

Description of the methodology used for the education experience of connecting students and potential employers by flipped classroom and use of ICTs

\section{Evaluation}

\section{Students' evaluation}

The spider diagram (Fig. 2) shows a high overall satisfaction of the students with the innovative experience as it has been proven by the global scoring of 4.3 out of 5 . Analyzing the particular items, the students appreciate to work in a real case, which was scored with 4.1 points out of 5.0; the use of ICT was scored with 4.2 out of 5 , indicating a high involvement with the technological innovation and communication media Also 4.2 out of 5 was satisfied by the practices to reach the concepts (flipped methodology). Conversely the lowest score corresponded to the ability of this methodology to bring the students closer to the labor market (sector) with 3.8/5, although the obtained score indicates that in general the objective has been reached.

Interestingly, the global satisfaction with the teaching-learning experience was lower in Master's students than in undergraduate students (data not shown), whereas the Master's students appreciated the use of ICTs and to work in a real case more than the undergraduate students. Conversely, undergraduates appreciated more to start with the practices in the subject (flipped).

Evaluation of an innovative teaching methodology for engineering involving companies and ICTs in a 


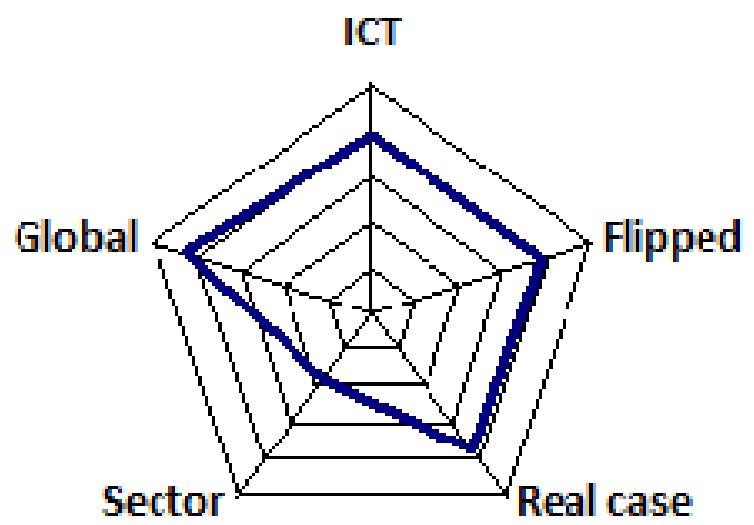

Figure 2.

Spider diagram of satisfaction of the students with the experience of connecting students and potential employers by flipped classroom and use of ICTs

\section{Lecturer's evaluation}

The lecturers pointed out that during the implementation of the action the following contingencies need to be overcome:

1. the lack of alignment between the problems that the companies need to solve and the curricula of the students

2. the reluctance of the technological companies to share their problems with the academia

3. the difficulty of application of the methodology for fundamental subjects

4. the difficulty of application of the methodology with students of very different knowledge level

On the positive side, the teachers' assessment clearly indicated an improvement of the teaching-learning experience from several viewpoints: Firstly, the implementation of the flipped methodology to real cases leads to a better monitoring and assessment of the subject practices and allows the teachers a better follow-up of the learning progress. Secondly, lecturers believe that the flipped methodology induces the student creativity. Moreover, collaborative learning is another strong point, reached by group presentations with the feedback of the rest of the students. Collaborative work students-lecturers are enhanced in those cases in which the students actively participate in the process of selecting the company and the study case, designing their own subject practices.

Evaluation of an innovative teaching methodology for engineering involving companies and ICTs in a 
Finally, the interaction between the lecturers involved has proved to be a key point to improve the methodology. It would be interesting also a feedback from the rest of the academic community at the international level, not only from seminars but also by a suggestions mailbox on the webpage where the action is presented

\section{Conclusions}

The main conclusions derived from the obtained results are the following:

i) In students' opinion the use of real cases coming from the professional sector improves the practical teaching.

ii) The use of ICTs to solve real cases has been very appreciated by the students, and therefore it is encouraged an effort to improve their use.

iii) The flipped methodology promotes autonomous students’ learning.

iv) The experience has proved to be useful to promote a collaborative student-student and students-teachers work.

\section{References}

Berrett, D. (2012). How 'flipping' the classroom can improve the traditional lecture. Washington: The Chronicle of Higher Education, Feb. 19.

Brame, C. (2013). Flipping the classroom. Vanderbilt: Vanderbilt University Center for Teaching. http://cft.vanderbilt.edu/guides-sub-pages/flipping-the-classroom/

EACEA: Education, Audiovisual and Culture Executive Agency, European Commission. (2014). Modernization of Higher Education in Europe: Access, Retention and Employability, Eurydice Report. Luxemburg: European Commission. $\quad$ http://bookshop.europa.eu/is-bin/INTERSHOP.enfinity/WFS/EUBookshop-Site/en_GB/-/EUR/ViewPublication-

\section{Start?PublicationKey=EC0214422}

Fitzpatrick, M. (2012). Classroom lectures go digital. New York: The New York Times, June 24, 2012.

Kilian, T., Hennigs, N., \& Langner, S. (2012). Do Millennials read books or blogs? Introducing a media usage typology of the internet generation. Journal of Consumer Marketing, 29(2), 114-124.

Evaluation of an innovative teaching methodology for engineering involving companies and ICTs in a 
Mazur, E. (2009). Farewell, Lecture? Science, 323, 50-51.

Miller, J. (2014). The fourth screen: mediatization and the smartphone. Mobile Media \& Communication, 2(2), 209-226.

Web empresa 2.0. (2015). La herramienta analítica de la nueva era. Web log post. http://www.webempresa20.com/blog/herramientas-de-analitica-web.html. 